\title{
INDIRECT QUANTITATIVE IR ASSESSMENT OF MAXIMAL MONOMOLECULAR DEPOSITION OF 3-AMINOPROPYLTRIMETHOXYSILANE ON SILICA GEL SURFACE
}

\author{
Miha Bukleski*, Vladimir Ivanovski \\ Ss. Cyril and Methodius University, Faculty of Natural Sciences and Mathematics, \\ Institute of Chemistry, Arhimedova 5, 1000 Skopje, Republic of Macedonia \\ *mihabukleski@yahoo.com
}

\begin{abstract}
Quantification of the amount of maximum loaded 3-aminopropylsilyl (APS) on a thermally pretreated silica gel $\left(600^{\circ} \mathrm{C}\right)$ was performed using IR spectroscopy. Finding the maximum load through a construction of a Langmuir isotherm was not possible due to the irreversibility of the chemisorption reaction. The method used in this work was based on the analysis of the toluene solution on the quantity of the non-reacted 3-aminopropyltrimethoxysilane (APTMS) after the saturation of the silica gel surface with APS. The process of chemisorption was monitored via the increasing band intensity of $v\left(\mathrm{CH}_{2}\right), v\left(\mathrm{NH}_{2}\right)$, and $\delta\left(\mathrm{NH}_{2}\right)$ modes of the adsorbent and decreasing $v(\mathrm{OH})$ band intensity characteristic for the free isolated $\mathrm{OH}$ groups of silica gel using DRIFT spectroscopy. The results on maximum adsorption are in line with those previously obtained, using carbon elemental analysis and a direct DRIFT method.
\end{abstract}

Keywords: 3-aminopropyltrimethoxysilane (APTMS); chemisorption; DRIFT spectra; modified silica gel

\section{ИНДИРЕКТНО КВАНТИТАТИВНО ОПРЕДЕЛУВАЊЕ МАКСИМАЛНА МОНОМОЛЕКУЛАРНА ДЕПОЗИЦИЈА НА З-АМИНОПРОПИЛТРИМЕТОКСИСИЛАН НА ПОВРШИНАТА ОД СИЛИКАГЕЛ СО ИНФРАЦРВЕНА СПЕКТРОСКОПИЈА}

\begin{abstract}
Квантификацијата на максимално нафатеното количество 3-аминопропилсилил (APS) на температурно активиран силикагел $\left(600^{\circ} \mathrm{C}\right)$ беше спроведена со помош на инфрацрвена спектроскопија. Определувањето на максимално нафатеното количество преку конструкција на Лангмјурова изотерма не е можно како резултат на иреверзибилноста на хемиската реакција. Користениот метод во оваа работа беше базиран на анализа на растворот од толуен во однос на содржината на неизреагиран 3-аминопропилтриметоксисилан (APTMS) по заситувањето на површината на силикагелот со групи на APS. Процесот на хемисорпција беше следен преку зголемувањето на интензитетот на лентите од модовите на $v\left(\mathrm{CH}_{2}\right), v\left(\mathrm{NH}_{2}\right)$ и $\delta\left(\mathrm{NH}_{2}\right)$ од атсорбираните молекули и намалувањето на интензитетот на модот $v(\mathrm{OH})$ од слободните, т.е. изолирани OH- групи од силикагелот, со помош на DRIFT спектроскопијата. Добиените резултати за максималната атсорпција се во согласност со претходно добиените од елементарна анализа и со оние добиени со примена на директниот DRIFT-метод.
\end{abstract}

Клучни зборови: 3-аминопропилтриметоксисилан (APTMS); хемисорпција; DRIFT спектри; модифициран силика гел 


\section{INTRODUCTION}

The reason for extensive studies on the properties of silica gel and its structure [1-9] is related to the wide usage of this material in many scientific fields as well as technological development. Far more important though are the functionalized silica gel products obtained by deposition of different organic compounds. These have the properties of retaining silica gel rigid structure and stability and at the same time possess specific physical and chemical properties as the adsorbed organic compound. Such materials are widely used with a variety of applications as catalytic materials [10], but also in the field of analytical separations [11], electrochemistry and sensors [12]. The modified silica gel has usage in biochemistry in the processes of enzyme immobilization and encapsulation, and nowadays these techniques are well established and adapted for biosensor design, especially for producing nano-biosensors [13]. Modified silica gel is also used in column chromatography instead of regular silica gel, making it more efficient and significantly reducing the amount of solvent needed for the separation [14, 15]. Among others, amine-functionalized silica gel's applications play an important role $[8,16]$.

One way to functionalize silica gel with amino groups is by using aminoorganosilanes - compounds containing one and up to three OR groups and also an $\mathrm{NH}_{2}$ group. The general formula for aminoorganotrioxysilanes is $\mathrm{NH}_{2}-\mathrm{R}^{\prime}-\mathrm{Si}(\mathrm{OR})_{3}$, where $\mathrm{R}^{\prime}$ is the organic group (usually aliphatic chain), and $\mathrm{R}$ is the short aliphatic group (usually $\mathrm{CH}_{3}$ or $\mathrm{C}_{2} \mathrm{H}_{5}$ ).

The chemical deposition (chemisorption) of aminoorganosilanes can be done either by the method of anhydrous liquid phase deposition when a monomolecular layer is being formed (as used in this work), or by the method of aqueous deposition when a layer of polymerized APTMS (3-aminopropyltrimethoxysilane) absorbed on the surface can be detected $[8,16]$. The surface of the silica gel, the degree of hydration [17], and the type of available $\mathrm{OH}$ groups play an important role in the formation of the monomolecular layer. Many papers deal with the deposition of different primary amines on silica gel surface [18-22], their use and characterization, including DRIFT spectra studies. However, there are few studies on quantitative determination of the amount of adsorbed organic compound on the silica surface.

The quantification of the APS on silica gel can be done in a direct or indirect way. Direct quantification using IR spectroscopy mainly employs DRIFT spectroscopy for the purpose [23].
This spectroscopy technique is not invasive and is applicable for in-situ investigations. The indirect spectroscopy methods are concerned with finding the unreacted amount of adsorbent, and by knowing the initially used amount, finding the adsorbed quantity of APS. For example, the direct quantification using DRIFT spectroscopy has been applied in [23-25], where it has been shown that linearity between the adsorbent load on the substrate and the intensity of the adsorbent bands exists. In order to quantify as well as find the maximum amount of adsorption, a construction of an isotherm is the usual procedure. This can be done by knowing the quantities of the adsorbent on the surface and in the solution at equilibrium [24, 25]. Such a procedure works very well when adsorption is an actual physisorption and when equilibrium is established. However, if the process of adsorption is an actual chemisorption and the reaction is irreversible, then the equilibrium concentration in the solution will be negligible, without the possibility of being measured (particularly not using IR). The reaction between the ethoxy (methoxy) groups and the $\mathrm{OH}$ groups from the silica gel (used in this work) is an example of such irreversible reaction [26].

In this work, indirect method in assessing the maximum chemisorption was used, by quantifying the APTMS in the toluene solution and knowing the starting amounts of APTMS. The obtained results are in agreement with our previous results, employing a direct DRIFT method and carbon elemental analysis [27]. The indirect method for determination of the maximal amount of the chemisorbed APS fragments on the silica gel surface employs easier experimental methodology than the direct DRIFT technique in the sense that it does not require inert conditions during the sample preparation for the IR recording and for the recording itself. It also applies transmission IR, which in the view of many authors is much more suitable for quantification purposes than the DRIFT technique used in the direct method. As previously mentioned, however, this does not diminish the importance of the DRIFT method, which is in-situ.

\section{EXPERIMENTAL PART}

\subsection{General settings}

Strict precautions were taken to obtain moisture free atmosphere so that all of the experiments, including sample preparation, DRIFT recordings, manipulation with substances, and glassware, were done in inert conditions either using a Schlenk line system or a glovebox. All the glassware used in the 
experiments was first silanized with dichlorodimethyl silane using vacuum desiccator [28]. The IR spectrophotometer was purged with a stream of $\mathrm{N}_{2}$ gas (99.999\% purity). Also, for the process of deposition of APTMS on dried silica gel, anhydrous solvents (toluene $99.8 \%$ and diethyl ether 99.7 $\%$ ) with maximum $0.005 \% \mathrm{H}_{2} \mathrm{O}$, purchased from Merck Chemicals $\mathrm{GmbH}$, were used as received, while the $97 \%$ APTMS (3-aminopropyltrimethoxysilane) was distilled prior to use.

\subsection{Deposition procedure}

The deposition was done under inert conditions (using Schlenk line and $\mathrm{N}_{2}$ as an inert gas). First, an exact mass (with accuracy of $\pm 0.0001 \mathrm{~g}$ ) of dried silica gel was weighted and poured into a flask. Afterward, according to the mass of the dried silica gel, volumes of standard APTMS solution and dry toluene were calculated and added in the flask, so that the total volume was $15 \mathrm{ml}$. The mixture was refluxed for $24 \mathrm{~h}$ using Dean-Stark apparatus. Then, the toluene was removed under reduced pressure and the silica gel with the attached APTMS (both chemisorbed and physisorbed) was vacuum dried for two hours at $180^{\circ} \mathrm{C}$. For DRIFT measurements exclusively, the functionalized silica gel was transferred to a Soxhlet extractor and the extraction with dry diethyl ether proceeded for $12 \mathrm{~h}$ in order to eliminate the remaining physisorbed APTMS on silica gel. The remaining ether was also removed under reduced pressure. As a result, only a chemisorbed APTMS was present on the silica gel surface. A second Dean-Stark refluction was conducted to collect all the physisorbed APTMS from silica gel into a toluene solution, for the IR absorption measurements. Instead of refluction, a Soxhlet extraction with toluene as solvent would probably have given the same result. The Soxhlet extraction used at the end of this process with diethyl ether as solvent was applied to determine whether all the physisorbed APTMS was really transferred into toluene during the second Dean-Stark refluction. The flow chart on the deposition procedure and analysis is given below.

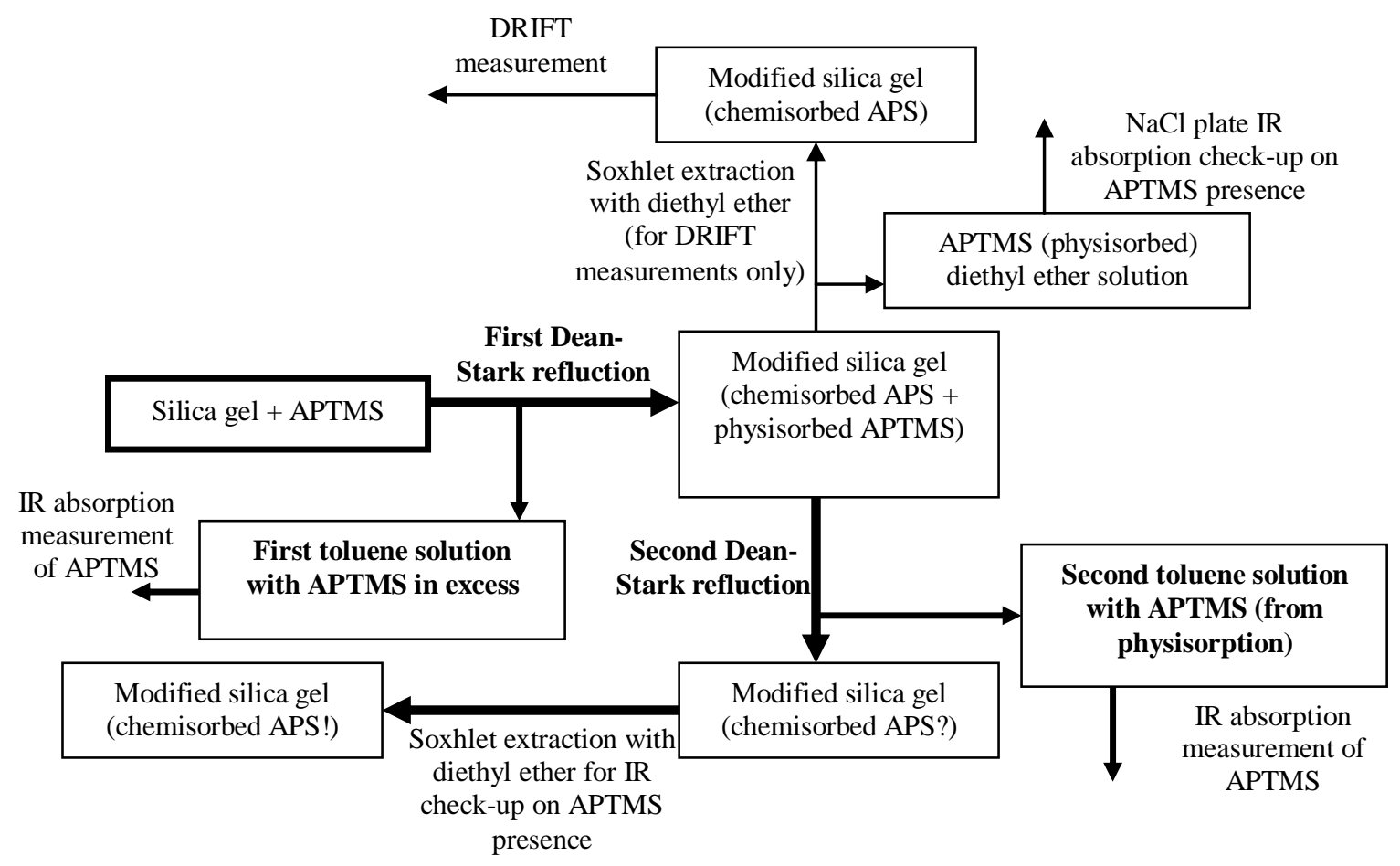

The silica gel used for the experiments was commercially available; "Geduran Si60 for column chromatography" with $0.040-0.063 \mathrm{~mm}$ mesh particle size, pore size of $60 \AA$ purchased from Merck Chemicals GmbH. The measured BET surface area of the silica gel was $589 \mathrm{~m}^{2} / \mathrm{g}[27,29]$.

\subsection{Sample preparation for IR recordings}

The sample preparation was done by mixing an exact mass of functionalized silica gel and $\mathrm{KBr}$ (pre-dried under vacuum at $200{ }^{\circ} \mathrm{C}$ ) in ratio $1: 10$, using vibrating mill. 
For the measurement of the content of APTMS in toluene obtained after the Dean-Stark refluction, a liquid sampling cell with $\mathrm{CsBr}$ plates and $0.05 \mathrm{~mm}$ spacer was used. Dry toluene was used for the background spectrum.

The detection of the presence of APTMS after the Sohxlet extraction with diethyl ether was performed using IR transmittance spectroscopy. For this purpose, the diethyl ether was firstly concentrated by evaporation of the solvent in $\mathrm{N}_{2}$ stream and then the concentrated solution was applied on the $\mathrm{NaCl}$ plate dropwise on one spot, allowing the solvent to evaporate completely. Then, an IR spectrum of the plate with the left-over was recorded.

\subsection{Instrumentation}

All IR spectra were recorded on a PerkinElmer System 2000 FTIR Spectrometer. The DRIFT spectra were recorded using Perkin-Elmer Diffuse Reflectance Accessory employing dilution technique [30]. The spectra were recorded using $2 \mathrm{~cm}^{-1}$ resolution and 32 scans for the background spectrum and 64 scans for the sample spectrum. For the IR recordings of the liquid samples, the instrument settings remained the same, except for the number of scans that were increased (64 scans for the background spectrum and 128 scans for the sample spectrum), in order to achieve better signal to noise ratio. The spectra of the liquid samples were recorded in non-inert atmosphere since they were not moisture sensitive and the samples could be manipulated with no danger of water adsorption.

\section{RESULTS AND DISCUSSION}

\subsection{Chemisorption of APTMS on silica gel}

The first step of the process of obtaining the modified silica gel was the activation process of silica gel. To this end, IR spectra of vacuum dried silica gel on different temperatures were recorded and the obtained results were compared (Fig. 1).

A particular feature in the DRIFT spectra of silica gel is the band at $3747 \mathrm{~cm}^{-1}$, which originates from the stretching vibrations of the isolated free $\mathrm{OH}$ groups $[2,8,31,32]$. The free $\mathrm{OH}$ groups come into interaction with the $\mathrm{MeO}$ groups from the APTMS and chemical $\mathrm{Si}-\mathrm{O}-\mathrm{Si}$ bond is formed as shown in the case of monodentate bonding by the equation:

$\mathrm{H}_{2} \mathrm{~N}-\left(\mathrm{CH}_{2}\right)_{3}-\mathrm{Si}(\mathrm{OMe})_{3}+\mathrm{HO}-\mathrm{Si}$-silica gel $\rightarrow \mathrm{H}_{2} \mathrm{~N}$ $\left(\mathrm{CH}_{2}\right)_{3}-\mathrm{Si}(\mathrm{OMe})_{2}-\mathrm{O}-\mathrm{Si}$-silica gel $+\mathrm{MeOH}$

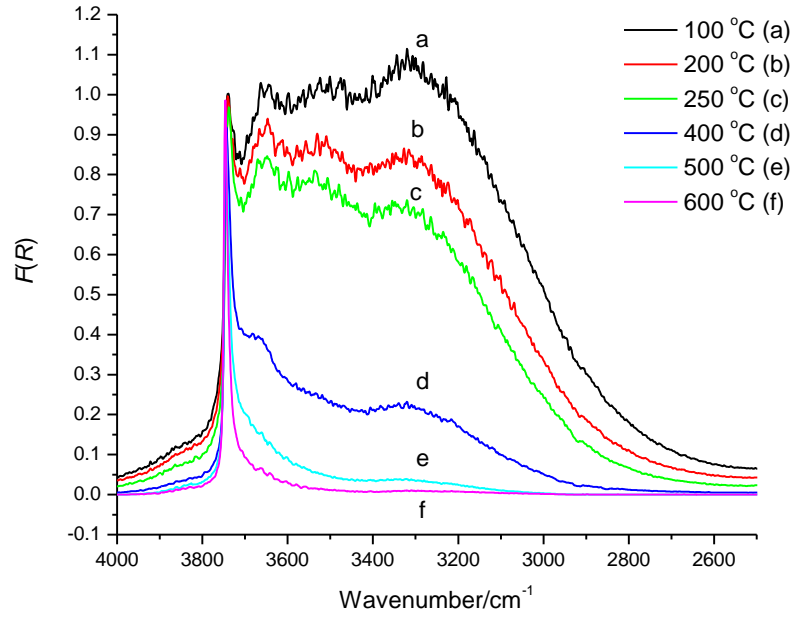

Fig. 1. DRIFT spectra of vacuum dried silica gel on different temperatures in the region of the $\mathrm{OH}$ and $\mathrm{H}_{2} \mathrm{O}$ stretching vibrations

The process of chemisorption leads to a decreasing intensity of the band at $3747 \mathrm{~cm}^{-1}$. As the weight fraction of APTMS (w/w APTMS) in the suspension increased, the band in question decreased in the APS modified product (Fig. 2A) until it almost vanished. The term weight fraction of APTMS which will be used throughout this study represents the mass fraction of APTMS in the system APTMS + silica gel, present at the beginning of the reaction of chemisorption.

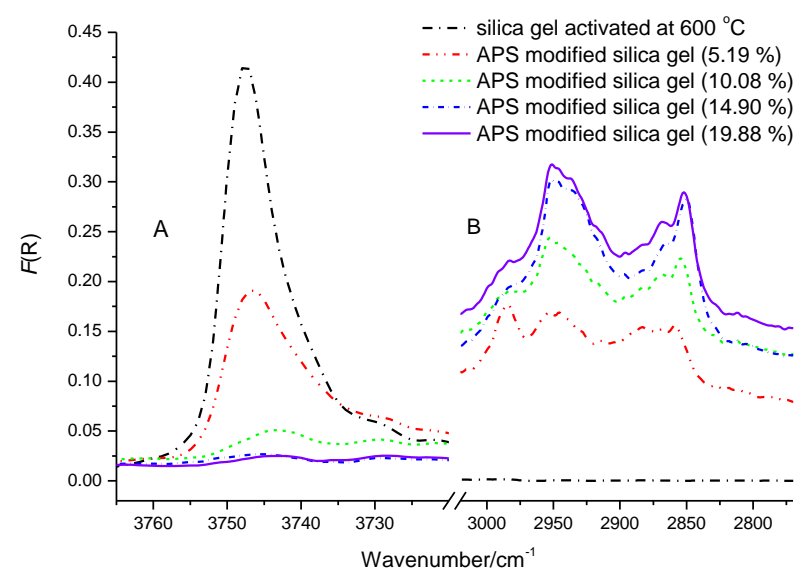

Fig. 2. DRIFT spectrum of silica gel activated at $600{ }^{\circ} \mathrm{C}$ and APS functionalized silica gel in the region of stretching vibration of free $\mathrm{OH}$ groups (A) and stretching vibrations of $\mathrm{CH}_{2}$ groups (B). The intensity of the band at $3747 \mathrm{~cm}^{-1}$ decreases, while the intensity of the complex bands in the region from $3000 \mathrm{~cm}^{-1}$ to $2830 \mathrm{~cm}^{-1}$ increases as the w/w APTMS increases

The spectra obtained from the APS functionalized silica gel overlapped when the w/w APTMS was above $19.88 \%$, (Fig. 3). This suggests that the maximum adsorption of the APS linker was reached for w/w APTMS below $19.88 \%$. 
Another spectral feature indicating that chemisorption was successful, were the bands in the region from $3000 \mathrm{~cm}^{-1}$ to $2830 \mathrm{~cm}^{-1}$, originating from the stretching vibrations of the $\mathrm{CH}_{2}$ groups from the APS fragment present in the product. As the amount of APTMS increased, the intensity of the bands also increased (Fig. 2B and Fig. $3 \mathrm{~B})$ until it reached its maximum at $19.88 \%$. Afterward, as the amount of APTMS increased the intensity of the bands did not change (Fig. 3B).

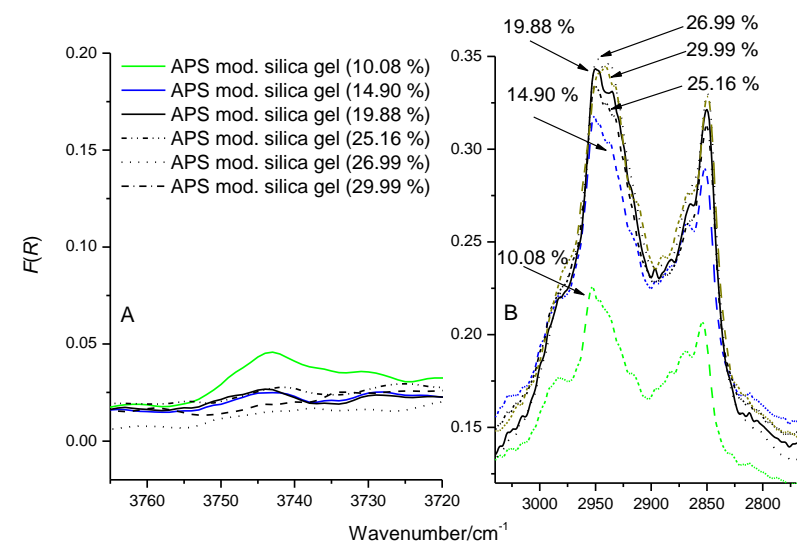

Fig. 3. DRIFT spectrum of APS functionalized silica gel in the region of stretching vibration of free $\mathrm{OH}$ groups (A) and stretching vibrations of $\mathrm{CH}_{2}$ groups (B) for w/w APTMS in the range of $\approx 21 \%$ to $\approx 30 \%$. The intensity of the bands remained almost unchanged.

Another confirmation that the process of chemisorption occurred was the increase of the bands of $\delta\left(\mathrm{NH}_{2}\right), v\left(\mathrm{NH}_{2}\right)$, and $\delta\left(\mathrm{CH}_{2}\right)$ vibrations (cf. Fig. 4). In this region bands can be seen originating from the APS fragment of the functionalized product with the assignment given in Figure 4 according to ref. [33]. Although the change is quite visible for $\delta\left(\mathrm{NH}_{2}\right)$ and $\delta\left(\mathrm{CH}_{2}\right)$ bands, this is not the case for the $v\left(\mathrm{NH}_{2}\right)$, due to the much lower intensity.

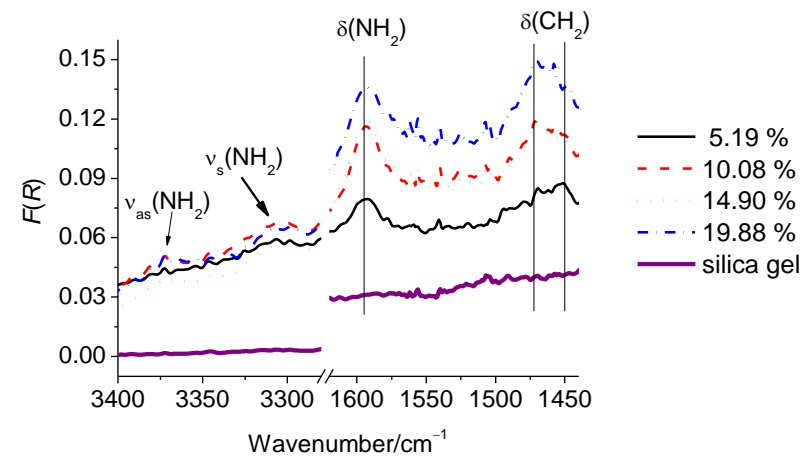

Fig. 4. DRIFT spectra in the region of stretching symmetric and asymmetric $\mathrm{NH}_{2}$ vibrations (left) and the region of bending $\mathrm{NH}_{2}$ and $\mathrm{CH}_{2}$ vibrations (right) from APS modified silica gel containing different amounts of APS. Bands show presence of species characteristic for the APS fragment.

\subsection{Determining the maximum amount of attached APS}

A usual way to obtain the maximum adsorption of a monomolecular layer on the silica gel surface is by constructing a Langmuir isotherm. As already mentioned in the Introduction section, the reaction between the methoxy groups from the APTMS and the free $\mathrm{OH}$ from the activated silica gel is irreversible [26]. Thus, almost all APTMS will be chemisorbed from the toluene solution on the silica gel surface, until the maximum APS chemisorption occurs. Under this condition, it was possible to obtain the APTMS load at which a maximum APS load on the silica gel occurred.

\subsubsection{Calibration curve and quantification limit for APTMS in toluene}

A series of eight solutions were prepared with exact values for the molar concentration of the dissolved APTMS in toluene. The IR spectra and the APTMS concentration of the solutions are given in Figure 5.

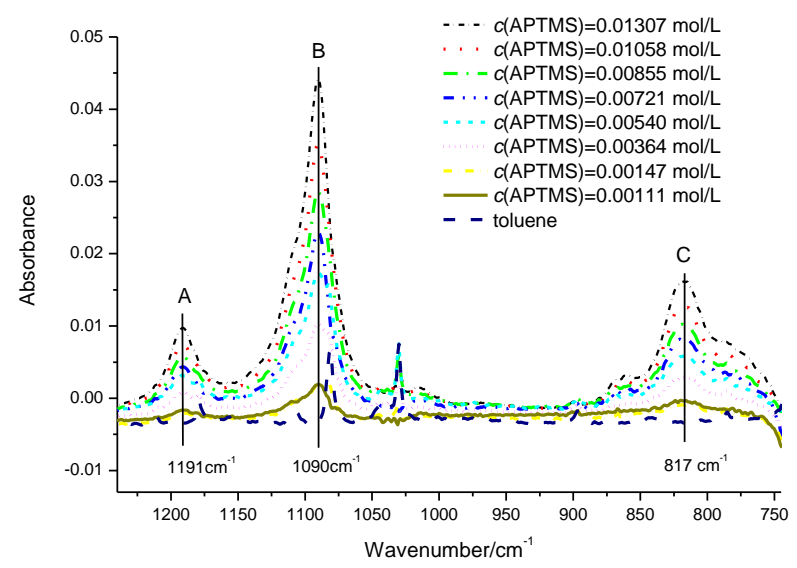

Fig. 5. Absorption IR spectra of APTMS solution in dry toluene with different molar concentrations. The IR spectrum of dry toluene is also given for comparison. The presence of APTMS can be detected in all recorded spectra. (A) band $1191 \mathrm{~cm}^{-1}, v\left(\mathrm{O}-\mathrm{CH}_{3}\right)$; (B) band $-1090 \mathrm{~cm}^{-1}, v(\mathrm{Si}-\mathrm{O}-\mathrm{C})$ [34]; (C) band $-817 \mathrm{~cm}^{-1}, \omega\left(\mathrm{NH}_{2}\right)$ and $\tau\left(\mathrm{NH}_{2}\right)$ [35]. The band assignment is tentative.

Even though APTMS concentration of $0.00111 \mathrm{~mol} / \mathrm{l}$ can be detected, this value shows very large deviations from the linearity when the calibration curves were constructed and, therefore, cannot be used for analytical purpose. Thus, the lowest quantification limit for APTMS in toluene solution was estimated at the first higher measured value of $0.001472 \mathrm{~mol} / \mathrm{l}$.

According to the Beer-Lambert law, the concentration is linear with the absorbance. In the case 
of the absorbance IR spectra, the integrated intensity i.e. the area under the band and band height are proportional with the concentration. The band area and the band height were calculated using GRAMS software [36] and are given in Table 1.

The integration region for band $\mathrm{A}$ was from $1206.5 \mathrm{~cm}^{-1}$ to $1185 \mathrm{~cm}^{-1}$. For band $\mathrm{B}$, best results were obtained when the integration was done in the region from $1147 \mathrm{~cm}^{-1}$ to $1055 \mathrm{~cm}^{-1}$, while for band $\mathrm{C}$ the integration region was from $850 \mathrm{~cm}^{-1}$ to $793 \mathrm{~cm}^{-1}$.

Using the data from Table 1, correlations between the band intensities and the band heights (Fig. 6) with concentration of w/w APTMS can be given. Diagrams show excellent linear dependence with values for the square correlation coefficient $R^{2}$ for the bands A, B, and C, both for the band surfaces and band heights.

Table 1

Average band intensities and band heights for the three APTMS bands as a function of the APTMS concentration. Three measurements have been performed per APTMS load.

\begin{tabular}{lrrrrrrrr}
\hline \hline$c \cdot 10^{-3} / \mathrm{mol} \mathrm{l}^{-1}$ & & 1.472 & 3.643 & 5.40 & 7.217 & 8.546 & 10.60 & 13.07 \\
\hline \multirow{3}{*}{ Intensity $\cdot 10^{-3}$ /a.u. } & $\mathrm{A}$ & $6.5(6)$ & $13(1)$ & $19(1)$ & $26(1)$ & $29.7(5)$ & $35.8(4)$ & $44.7(8)$ \\
& $\mathrm{B}$ & $150(9)$ & $380(9)$ & $559(9)$ & $708(9)$ & $847(1)$ & $1036(7)$ & $1280(1)$ \\
& $\mathrm{C}$ & $32(3)$ & $83(3)$ & $123(2)$ & $158(4)$ & $189(5)$ & $234(2)$ & $286(5)$ \\
\hline & $\mathrm{A}$ & $0.56(2)$ & $1.12(5)$ & $1.61(4)$ & $2.10(8)$ & $2.51(2)$ & $3.02(7)$ & $3.66(8)$ \\
Height $\cdot 10^{-3}$ /a.u. & $\mathrm{B}$ & $4.7(1)$ & $11.86(5)$ & $17.6(2)$ & $2.34(2)$ & $27.6(1)$ & $33.9(1)$ & $42.4(7)$ \\
& $\mathrm{C}$ & $1.3(1)$ & $3.11(1)$ & $4.6(1)$ & $5.88(1)$ & $7.06(8)$ & $8.62(6)$ & $10.7(2)$ \\
\hline \hline
\end{tabular}
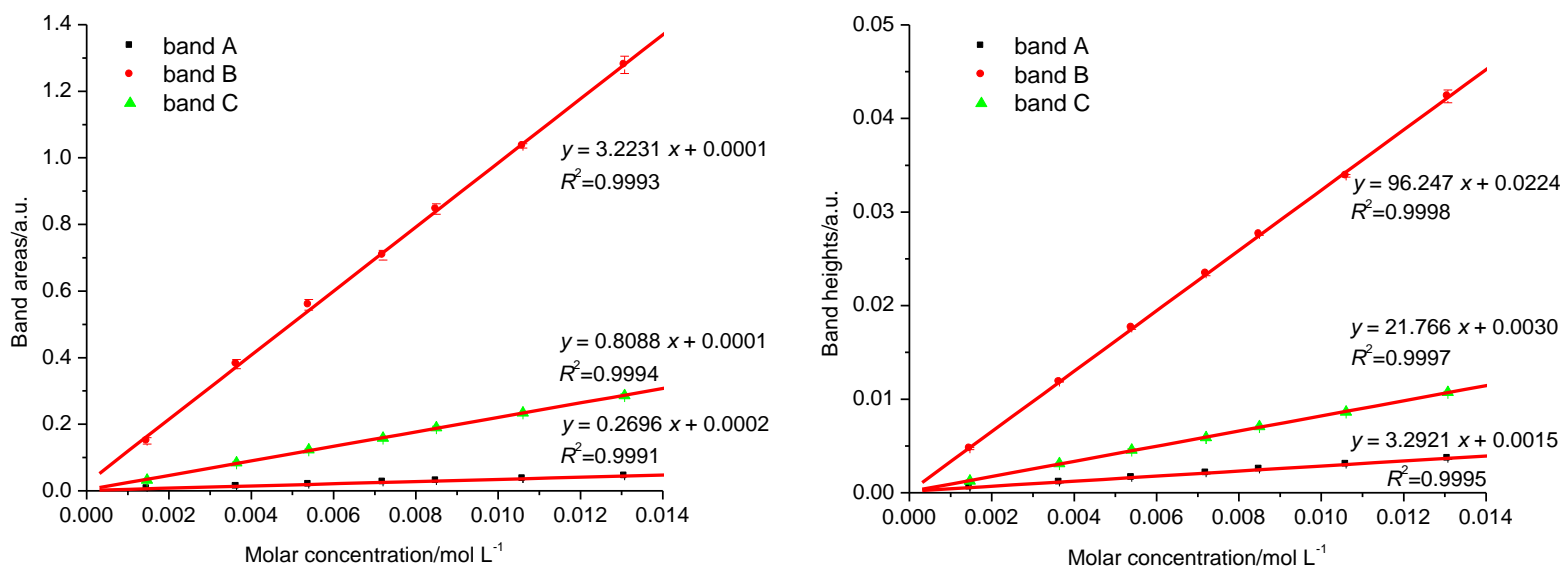

Fig. 6. Correlation diagram for the dependence of the intensities and heights of the bands A, B, and C from the concentration of APTMS in toluene.

\subsubsection{Assessing the maximum APS load}

In order to assess the maximum amount of APS attached, a series of 11 samples were prepared with different w/w APTMS (Table 2). The last column gives the data on the visual presence of bands from APTMS in the IR spectra of toluene, collected after the reaction. Representative spectra are shown in Figure 7.

From the absorbance IR spectra in Figure 7 and the data presented in Table 2, it appears that w/w APTMS for maximum APS adsorption was somewhere between $18.19 \%$ and $19.70 \%$. One important step in the methodology was the assurance that APTMS has been chemisorbed as APS and there was no APTMS physisorbed for loads $>19.70 \%$. The excess of physisorbed APTMS was removed from the silica gel surface employing second Dean Stark refluction. Three samples with APTMS load of $19.70 \%, 25.16 \%$, and $29.80 \%$ were analyzed in this way. After the double refluction, the obtained functionalized product was subjected to extraction with diethyl ether. In the spectra of diethyl ether solutions (recording procedure explained in the Experimental part), no bands from 
APTMS were detected. Thus, all the APTMS adsorbed was actually chemisorbed, while the excess APTMS remained in the second toluene solution.

Table 2

Loading of APTMS on silica gel and the detection of the excess APTMS in the solution after the first Dean Stark refluction.

\begin{tabular}{ccccc}
\hline \hline $\begin{array}{c}m(\text { silica } \\
\text { gel }) \\
{[\mathrm{g}]}\end{array}$ & $\begin{array}{c}V \text { (APTMS) } \\
{[\mathrm{ml}]} \\
c=0.3667 \\
\mathrm{~mol} / \mathrm{l}\end{array}$ & $\begin{array}{c}{[n(\text { APTMS }) /} \\
m(\text { silica gel })] \\
{[\mathrm{mol} / \mathrm{g}]}\end{array}$ & $\begin{array}{c}\mathrm{w} / \mathrm{w} \\
\text { APTMS } \\
{[\%]}\end{array}$ & $\begin{array}{c}\text { Presence } \\
\text { of } \\
\text { APTMS }\end{array}$ \\
\hline 1.3200 & 1.100 & $0.306 \cdot 10^{-3}$ & 5.19 & $\mathbf{x}$ \\
1.1732 & 2.000 & $0.625 \cdot 10^{-3}$ & 10.08 & $\times$ \\
1.0514 & 2.800 & $0.976 \cdot 10^{-3}$ & 14.90 & $\times$ \\
1.2183 & 4.120 & $1.234 \cdot 10^{-3}$ & 18.19 & $\times$ \\
1.2991 & 4.800 & $1.353 \cdot 10^{-3}$ & 19.70 & $\checkmark$ \\
1.1126 & 4.200 & $1.384 \cdot 10^{-3}$ & 19.88 & $\checkmark$ \\
1.1001 & 5.000 & $1.667 \cdot 10^{-3}$ & 23.01 & $\checkmark$ \\
1.1731 & 6.000 & $1.876 \cdot 10^{-3}$ & 25.16 & $\checkmark$ \\
0.8891 & 5.000 & $2.062 \cdot 10^{-3}$ & 26.99 & $\checkmark$ \\
1.3144 & 8.490 & $2.369 \cdot 10^{-3}$ & 29.80 & $\checkmark$ \\
1.0285 & 6.700 & $2.389 \cdot 10^{-3}$ & 29.99 & $\checkmark$ \\
1.2271 & 9.200 & $2.749 \cdot 10^{-3}$ & 33.02 & $\checkmark$ \\
\hline \hline
\end{tabular}

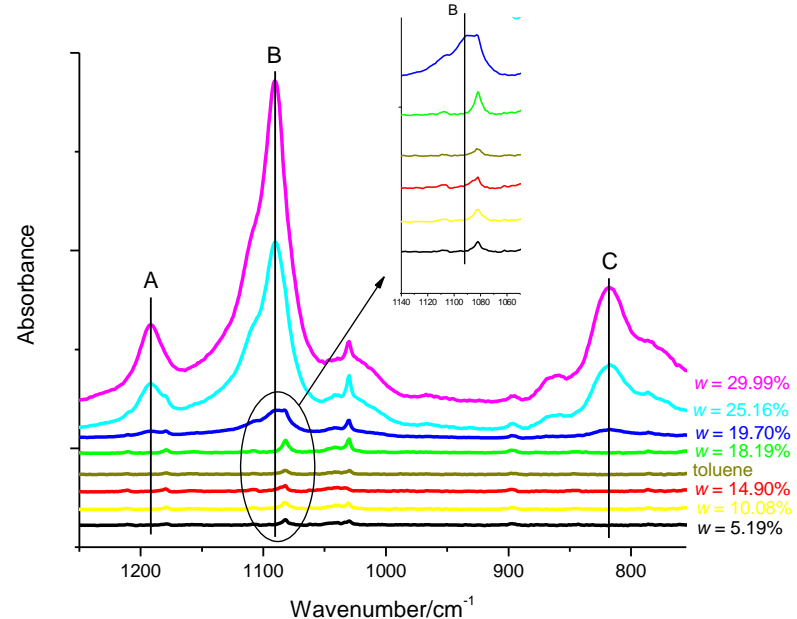

Fig. 7. Absorbance IR spectra of the solutions after Dean Stark refluction with different w/w APTMS (from $\approx 5 \%$ to $\approx 30 \%$ ) and pure toluene for comparison. The A, B, and C bands indicate the presence of unreacted APTMS in the toluene solution.

The bands' integrated intensity and height were afterwards obtained for the three samples (Table 3). Using calibration curves (Fig. 6), the concentration and thus the amount of the total nonchemisorbed APTMS was calculated. These amounts of the free APTMS were further normalized per gram of silica gel, according to the values given in Table 2. The obtained values for the unreacted APTMS are given in Table 3.

T a b le 3

Average intensities and heights of the A, B, and $C$ bands for three different $w / w$ APTMS samples

\begin{tabular}{|c|c|c|c|c|c|}
\hline w/w APTMS & $19.70 \%$ & $25.16 \%, \mathrm{I}$ & $25.16 \%$, II & $29.80 \%, \mathrm{I}$ & $29.80 \%$, II \\
\hline \multicolumn{6}{|c|}{ Average band intensities/a.u. } \\
\hline Band A & $0.012(1)$ & $0.0900(6)$ & $0.0400(4)$ & $0.1837(7)$ & $0.122(7)$ \\
\hline Band B & $0.35(2)$ & $2.503(5)$ & $1.156(9)$ & $5.457(3)$ & $3.450(1)$ \\
\hline Band C & $0.070(1)$ & $0.5731(4)$ & $0.261(1)$ & $1.231(8)$ & $0.779(3)$ \\
\hline \multicolumn{6}{|c|}{ Average band heights/a.u. } \\
\hline Band A & $0.00101(6)$ & $0.00730(4)$ & $0.00330(3)$ & $0.01546(8)$ & $0.00969(9)$ \\
\hline Band B & $0.0109(1)$ & $0.08240(3)$ & $0.0385(3)$ & $0.1814(2)$ & $0.116(1)$ \\
\hline Band C & $0.0027(1)$ & $0.02147(5)$ & $0.00990(5)$ & $0.0457(2)$ & $0.0290(1)$ \\
\hline \multicolumn{6}{|c|}{ Average amount of APTMS per gram of silica gel ${ }^{*} / \mathrm{mol} \mathrm{g}^{-1}$ (from intensities) } \\
\hline Band A & 0.000037 & 0.000390 & 0.000172 & 0.000631 & 0.000419 \\
\hline Band B & 0.000039 & 0.000380 & 0.000173 & 0.000644 & 0.000406 \\
\hline Band C & 0.000036 & 0.000390 & 0.000175 & 0.000644 & 0.000407 \\
\hline Average & 0.000037 & 0.000390 & 0.000173 & 0.000640 & 0.000411 \\
\hline Sum & & \multicolumn{2}{|c|}{0.000563} & \multicolumn{2}{|c|}{0.001051} \\
\hline \multicolumn{6}{|c|}{ Average amount of APTMS per gram of silica gel ${ }^{*} / \mathrm{mol} \mathrm{g}^{-1}$ (from heights) } \\
\hline Band A & 0.000036 & 0.000389 & 0.000171 & 0.000647 & 0.000403 \\
\hline Band B & 0.000038 & 0.000375 & 0.000175 & 0.000642 & 0.000409 \\
\hline Band C & 0.000037 & 0.000388 & 0.000178 & 0.000643 & 0.000408 \\
\hline Average & 0.000037 & 0.000384 & 0.000175 & 0.000644 & 0.000407 \\
\hline Sum & & \multicolumn{2}{|c|}{0.000559} & \multicolumn{2}{|c|}{0.001051} \\
\hline
\end{tabular}


Three measurements for each w/w APTMS sample were performed and the values were averaged. I and II refer to toluene solutions (containing excess APTMS or containing physisorbed APTMS, respectively) of the corresponding sample obtained after the first and the second refluction. On the basis of these data and the correlation diagrams (Fig. 6), the average amount of non-chemisorbed APTMS per gram of silica gel physisorbed was calculated.

Using the values for the free (non-chemisorbed), i.e. unreacted average amount of APTMS per gram silica gel (Table 3) and the starting amount of APTMS for the functionalization of the silica gel (Table 2), the w/w APTMS at which a maximum APS load occurred was calculated (Table 4).

\section{Table 4}

w/w APTMS, w/w APTMS for which maximal APS adsorption occurs and the concentration $C$ of APS as amount per square surface of silica gel

\begin{tabular}{|c|c|c|}
\hline $\begin{array}{c}\mathrm{w} / \mathrm{w} \text { APTMS } \\
\%\end{array}$ & $\begin{array}{c}\mathrm{w} / \mathrm{w} \text { APTMS max } \\
\%\end{array}$ & $\begin{array}{c}C(\text { APS }) \\
\mu \mathrm{mol} \cdot \mathrm{m}^{-2}\end{array}$ \\
\hline 19.70 & 19.04 & 2.23 \\
\hline 25.16 & 19.04 & 2.23 \\
\hline 29.80 & 19.05 & 2.24 \\
\hline Average & 19.04 & 2.23 \\
\hline
\end{tabular}

It was also possible to calculate the concentration of APS on the silica gel surface $(2.23 \mu \mathrm{mol}$ $\mathrm{m}^{-2}$ ), knowing that the molar ratio of APTMS to APS is 1 and the BET surface of the silica gel $\left(589 \mathrm{~m}^{2} / \mathrm{g},[27,29]\right)($ Table 4).

Previous experiments performed on the same samples, but using a direct method of quantification based on DRIFT technique, led to the same value of $2.23 \mu \mathrm{mol} \mathrm{m} \mathrm{m}^{-2}$ adsorption, while carbon elemental analyses gave $2.22 \mu \mathrm{mol} \mathrm{m}^{-2}$ [27].

\section{CONCLUSIONS}

A successful chemisorption of APS on thermally activated silica gel at $600{ }^{\circ} \mathrm{C}$ was obtained. This was proven by the decrease of DRIFT intensity of the $v(\mathrm{OH})$ band of the free $\mathrm{OH}$ groups from silica gel. Silica gel activated at $600{ }^{\circ} \mathrm{C}$ was used for the investigations since in this case the chemical reaction involves only isolated free $\mathrm{OH}$ groups from the silica gel surface [32]. The increase in the band intensities of $v\left(\mathrm{CH}_{2}\right), v\left(\mathrm{NH}_{2}\right)$, and $\delta\left(\mathrm{NH}_{2}\right)$ from the attached APS groups, suggested that the maximum adsorption on the silica gel occurred for w/w APTMS at around $19 \%$. The nucleophilic substitution here used for grafting is an irreversible process [26], thus almost the entire amount of initially added APTMS was chemisorbed on the silica gel, until saturation occurred. This was the condition needed to find the unreacted amount of APTMS in the solution of toluene and subtract it from the initial amount, in order to calculate the chemisorbed one. Six calibration curves were constructed using three different bands from the IR absorption spectra of standard APTMS solutions in toluene (three for bands' height and three for bands' integrated intensity). All calibration curves showed excellent linearity with a $R^{2}$ higher than 0.999. Also, using these standard solutions, the lowest quantification limit was estimated to be $0.001472 \mathrm{~mol} / \mathrm{l}$.

From the 12 samples with different w/w APTMS, i.e. mass fraction of APTMS in the system silica gel + APTMS present in the toluene solution, the first signs of non-chemisorption appeared for $19.70 \%$. Using two samples with higher starting w/w APTMS of $25.16 \%$ and $29.80 \%$, the average w/w APTMS value at maximum APS chemisorptions was found to be $19.04 \%$. According to the BET surface value of $589 \mathrm{~m}^{2} / \mathrm{g}$ for the silica gel [27, 29], the calculated adsorption for APS was found to be $2.23 \mu \mathrm{mol} \mathrm{m}$. This value is the same as the one obtained by the direct DRIFT method $2.23 \mu \mathrm{mol} \mathrm{m}{ }^{-2}$ and very close to the one obtained from elemental analysis $2.22 \mu \mathrm{mol} \mathrm{m} \mathrm{m}^{-2}$ [27]. These results show that it is possible using an indirect IR transmission method to obtain the chemisorbed amount of adsorbent for the irreversible chemical reaction of APTMS on the silica gel.

Acknowledgements. Financial support by the Alexander von Humboldt Foundation (group linkage program, DEU/1032664) and the DAAD (Stability Pact for SouthEastern Europe, MatCatNet project ID 54759562) is gratefully acknowledged

\section{REFERENCES}

[1] P. F. McMillan; R. L. Remmele, Jr., Hydroxyl sites in $\mathrm{SiO}_{2}$ glass: A note on infrared and Raman spectra, Am. Mineral., 71, 772-778 (1986).

[2] G. D. Chukin, V. I. Malevich, Infrared spectra of silica, Zhurnal prikladnoï spektroskopii, 26, 294-301 (1977).

[3] G. D. Chukin, A. I. Apretova, Silica gel and aerosol IR spectra and structure, Translated from Zhurnal prikladnoï spektroskopii, 50, 639-646 (1989).

[4] Y. Kawano, S. Denofre, Y. Gushikem, Raman and infrared spectra of silica gel and niobium(V) oxide grafted on silica gel surface and their dependence on pretreatment temperatures, Vib. Spectrosc., 7, 294-302 (1994). 
[5] A. Bertoluzza, C. Faganano, Raman and IR spectra on Silica Gel Evolving toward glass, J. Non-Cryst. Solids, 48, 117-128 (1982).

[6] P. Innocenzi, Infrared spectroscopy of sol-gel derived silica-based films: a spectra-microstructure overview, $J$. Non-Cryst. Solids, 316, 309-319 (2003).

[7] A. V. Kiselev, V. I. Lygin, Infrared Spectra of Surface Compounds, John Wiley and Sons, New York, 1975.

[8] E. F. Vansant, P. Van Der Voort, K. C. Vrancken, Characterization and Chemical Modification of the Silica Surface, vol.93, Elsevier Science, Amsterdam, 1995.

[9] A. A. Christy, Quantitative Determination of surface area of silica gel particles by near infrared spectroscopy and chemometrics, Colloids Surf. B, 322, 248-252 (2008).

[10] M. M. Collinson, Analytical applications of organically modified silicates, Mikrochim. Acta, 129, 149-165 (1998).

[11] O. Lev, M. Tsionsky, L. Rabinovich, V. Glezer, S. Sampath, I. Pankratov, Organically modified sol-gel sensors, J. Gun, Anal. Chem., 67, 22-30 (1995).

[12] A. Walcarius, Electroanalysis with pure, chemically modified and sol-gel-derived silica-based materials, Electroanalysis, 13, 701-718 (2001).

[13] A. C. Pierre, The Sol-Gel Encapsulation of enzymes, Biocatal. Biotransfor., 22 145-170 (2004).

[14] S. Gunawan, S. Ismadji, Y. H. Ju, Design and operation of a modified silica gel column chromatography, $J$. Chin. Inst. Chem. Ing., 39, 625-633 (2008).

[15] J. C. B. Fernandes, G. O. Neto, L. T. Kubota, Use of column with modified silica for interfering retention in a FIA spectrophotometric method for direct determination of vitamin C in medicine, Anal. Chim Acta, 366, 11-22 (1998).

[16] Gelest Inc., Silane Coupling Agents: Connecting Across Boundaries, Gelest Inc., 2006.

[17] K. C. Vrancken, K. Possemiers, P. Van Der Voort, E. F. Vansant, Surface modification of silica gels with aminoorganosilanes, Coloid. Surface. A, 98, 235-241 (1995).

[18] V. R. Rai, S. Agarwal, Mechanism of self-catalytic atomic layer deposition of silicon dioxide using 3aminopropyl triethoxysilane, water, and ozone, Chem. Mater. 23, 2312-2316 (2011).

[19] C. Damia, S. Sarada, E. Deydier, P. Sharrock, Study of two hydroxyapatite/poly(alkoxysilane) implant coatings, Surf. Coat. Technol., 201, 3008-3015 (2006).

[20] T. G. Waddell, D. E. Leyden, M. T. DeBello, The nature of organosilane to silica-surface bonding, J. Am. Chem. Soc., 103, 5303-5307 (1981).

[21] M. Etienne, A. Walcarius, Analytical investigation of the chemical reactivity and stability of aminopropyl-grafted silica in aqueous medium, Talanta, 59, 1173-1188 (2003).

[22] S. Photong, V. Boonamnuayvitaya, Synthesis of APTMS-functionalized $\mathrm{SiO}_{2} / \mathrm{TiO}_{2}$ transparent film using peroxo titanic acid refluxed solution for formaldehyde removal, Water Air Soil Pollut., 210 453-461 (2010).

[23] R. S. S. Murthy, D. E. Leyden, Quantitative determination of (3-aminopropyl)trietoxysilane on silica gel surface using diffuse reflectance infrared Fourier transform infrared spectrometry, Anal. Chem., 58, 1228-1233 (1986).

[24] E. Pèrè, H. Cardy, O. Cairon, M. Simon, S. Lacombe, Quantitative assessment of organic compounds adsorbed on silica gel by FTIR and UV-VIS spectroscopies: the contribution of diffuse reflectance spectroscopy, Vib. Spectrosc., 25, 163-175 (2001)

[25] L. Vågberg, P. De Potocki, P. Stenius, Quantitative measurements of adsorbed aminosilanes on muscovite mica using diffuse reflectance infrared Fourier transform Spectroscopy, Appl. Spectrosc., 43, 1240-1248 (1989).

[26] I. Shimizu, A. Yoshino, H. Okabayashi, E. Nishio, C. J. O'Connor, Kinetics of interaction of 3-aminopropyltriethoxysilane on asilica gel surface using elemental analysis and diffuse reflectanceinfrared Fourier transform spectra, J. Chem. Soc., Faraday Trans., 93, 19711979 (1997).

[27] M. Bukleski, V. Ivanovski, E. Hey-Hawkins, A direct method of quantification of maximum chemisorption of 3-aminopropylsylil groups on silica gel using DRIFT spectroscopy, submitted to Spectrochim. Acta A.

[28] W. L. F. Armarego, C. L. L. Chai, Purification of Laboratory Chemicals, 5-th edition, MPG Books Ltd, Bodmin, Cornwall, United Kingdom, 2003.

[29] M. Madalska, P. Lönnecke, V. Ivanovski, E. HeyHawkins, Synthesis of 1,1',2-trisubstituted aryl-based ferrocenyl phosphines as precursors for immobilized ligands, Organometallics, 32, 5852-5861 (2013).

[30] G. Kortüm, Reflectance Spectroscopy, Springer-Verlag, Berlin, 1969.

[31] V. Ivanovski, M. Madalska, M. Bukleski, E. HeyHawkins, Vibrational spectra of chemisorbed ferrocenylphosphine derivative on silica gel modified with 3 aminopropylsilyl, Vib. Spectrosc., 69, 57-64 (2013).

[32] L. T. Zhuravlev, The surface chemistry of amorphous silica. Zhuravlev model, Colloid Surf. A, 173, 1-38 (2000).

[33] H. Okabayashi, I. Shimizu, E. Nishio, C. J. O'Connor, Diffuse reflectance infrared Fourier transform spectral study of the interaction of 3-aminopropyltrietoxysilane on silica gel. Behaviour of amino groups on the surface, Colloid. Polym. Sci., 275, 744-753 (1997).

[34] E. T. Vandenberg, L. Bertilsson, B. Liedberg, K. Uvdal, R. Erladsson, H. Elwing, I. Lundstrom, Structure of 3aminopropyl triethoxy silane on silicon oxide, J. Colloid. Interf. Sci, 147, 103-118 (1991).

[35] B. H. Stuart, Infrared Spectroscopy: Fundamentals and Applications, John Wiley \& Sons, Chichester, 2004.

[36] GRAMS/32, Galactic Industries Corporation, 1993. 
